\title{
Contested Spaces
}

\section{Houses and Temples in Roman Antiquity and the New Testament Ed. by David L. Balch and Annette Weissenrieder}

[Umstrittener Raum. Häuser und Tempel in der römischen Antike und im Neuen Testament.]

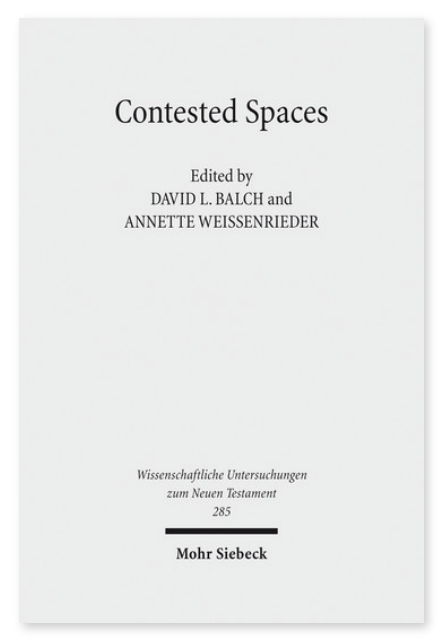

2012. XI, 561 Seiten ((inkl. CD)). WUNT I 285

ISBN 978-3-16-152026-6 DOI 10.1628/978-3-16-152026-6 eBook PDF 159,00€
Veröffentlicht auf Englisch.

Inwiefern bilden archäologische Erkenntnisse der Antike eine Grundlage zum Verständnis neutestamentlicher Texte wie beispielsweise dem Abendmahl? Wissenschaftler unterschiedlicher Disziplinen wie Archäologie, antiker Kunst und Neuem Testament widmen sich religiösen und paganen Räumen in der Kaiserzeit in Pompeji, Herculaneum, Rom, Ephesus oder Korinth. An erster Stelle steht ein archäologisches Anliegen: Es soll ein Einblick in die Eigenarten der Typologie in antiken Räumen wie Domus, Villae und Insulae vermittelt werden. Anschließend werden diese Raumtypologien in Beziehung zu neutestamentlichen Texten gestellt, um Fragen nach Leitungsformen, Mahlgemeinschaften, sozialen Beziehungen und ethischen Grundsätzen konziser beleuchten zu können. Ein weiteres Anliegen ist es, die Wechselwirkung von Architektur, Raumerfahrung, sozialem Handeln und religiöser Erfahrung in der Antike zu benennen.

Inhaltsübersicht

\section{A. Interpretive Issues}

John R. Clarke (University of Texas, Austin): Representations of Worship at Rome, Pompeii, Herculaneum, and Ostia in the Imperial Period: A Model of Production and consumption - Irene Bragantini (Università di Napoli - Orientale): The Cult of Isis and Ancient Aegyptomania in Campania - Fabrizio Pesando (Universita Orientale di Napoli): The Properties and the Social Role of Feminae Nobiles in Italy During the Early Imperial Age - Annette Weissenrieder (San Francisco Theological Seminary, Graduate Theological Union, Berkeley): Contested Spaces in 1 Corinthian 11:17-34 and 14:30: Sitting or Reclining in Ancient Houses, in Associations and in the Space of ekklēsia - Laura Salah Nasrallah (Harvard Divinity School): Grief in Corinth. The Roman City and Paul's Corinthian Correspondence - Eleanor Winsor Leach (Indiana University Bloomington): Rhetorical 'Inventio' and the Expectations of Roman Continuous Narrative Painting

\section{B. Contested Domestic spaces}

\section{Domus}

Ivan Varriale (Università degli Studi Suor Orsola Benincasa di Napoli): Architecture and Decoration in the House of Menander in Pompeii - Mario Grimaldi (Università degli Studi Suor Orsola Benincasa di Napoli - Université Paris X Nanterre): Art and Architecture of the House of Fabius Rufus in Pompeii - David L. Balch (Pacific Lutheran Theological Seminary, Graduate Theological Union, Berkeley): The Church Sitting in a Garden (1 Cor 14:30; Rom 16:23; Mark 6:39-40; 8:6; John 6:3, 10; Acts $1: 15 ; 2: 1-2)$ - Hilke Thür (University of Vienna): Art and Architecture in Terrace House 2 in Ephesos: An example of domestic architecture in the Roman Imperial Period

\section{Villae}

Umberto Pappalardo (Università degli Studi Suor Orsola Benincasa di Napoli): How the Romans saw the frieze in the Villa of the Mysteries - Rosaria Ciardiello (Università degli Studi Suor Orsola Benincasa di Napoli): Beryllos, the Jews and the Villa of Poppaea in Oplontis (Torre Annunziata) - Monika Bernett (University of Munich): Space and Interaction: Narrative and Representation of Power under the Herodians

\section{Insulae}

Maria Paola Guidobaldi (Director of excavations, Herculaneum): Insula Orientalis 1 in Herculaneum - Janet DeLaine (Oxford): Housing in Roman Ostia

\section{Contested Sacred Spaces: Temples, the Imperial Cult, and Mithraea}

Tina Najbjerg (Princeton University): Exploring the economic, political, and social significance of the great Porticus in Herculaneum - Annette Weissenrieder (San Francisco Theological Seminary, Graduate Theological Union, Berkeley): »Do you not know that you are God's temple?« Towards a new perspective on Paul's temple image in 1 Corinthians 3:16 - David L. Balch (Pacific Lutheran Theological Seminary, Graduate Theological Union, Berkeley): Cult Statues of Augustus' Temple of Apollo on the Palatine in Rome, Artemis'/Diana's Birthday in Ephesus, and Revelation 12:1-5a - L. Michael White (University of Texas at Austin): The Changing Face of Mithraism at Ostia. Archaeology, Art, and the Urban Landscape - Ulrike MusS (University of Vienna): The Artemesion at Ephesos: Paul, John and Mary

David L. Balch Born 1942; 1975 PhD Yale University; 1968/1987 two Fulbright grants to Tübingen; Professor of New Testament at Pacific Lutheran Theological Seminary, California Lutheran University and Graduate Theological Union.

Annette Weissenrieder Born 1967; Professor of Exegesis and Theology of New Testament at the Faculty of Theology at the Martin-Luther-University and director of the Institute »Corpus Hellenisticum«, University of Halle-Wittenberg.

Jetzt bestellen:

Mohr Siebeck GmbH \& Co. KG

Postfach 2040

D-72010 Tübingen

info@mohrsiebeck.com

www.mohrsiebeck.com 
https://mohrsiebeck.com/buch/contested-spaces-9783161520266?no_cache=1

order@mohrsiebeck.com

Telefon: +49 (0)7071-923-17

Telefax: $+49(0) 7071-51104$ 